GEOLOGICAL SURVEY CIRCULAR 784

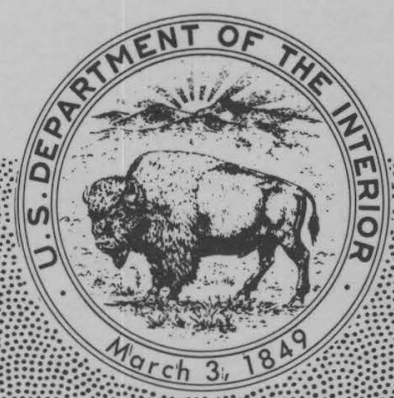

Gold, Silver, and Other Resources in the Ash of Incinerated Sewage Sludge at Palo Alto, California --

\author{
A Preliminary Report
}





\section{Gold, Silver, and Other Resources in the Ash of Incinerated Sewage Sludge at Palo Alto, California--A Preliminary Report}

By R. A. Gulbrandsen, Norma Rait, Donathan J. Krier, Philip A. Baedecker, and Anne Childress

\section{GEOLOGICAL SURVEY CIRCULAR 784}


United States Department of the Interior

CECIL D. ANDRUS, Secretary

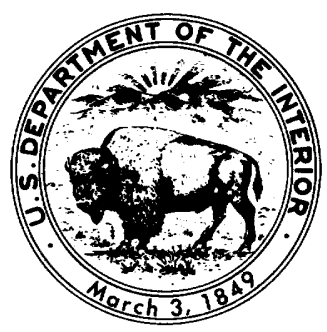

Geological Survey

H. William Menard, Director 


\section{CONTENTS}

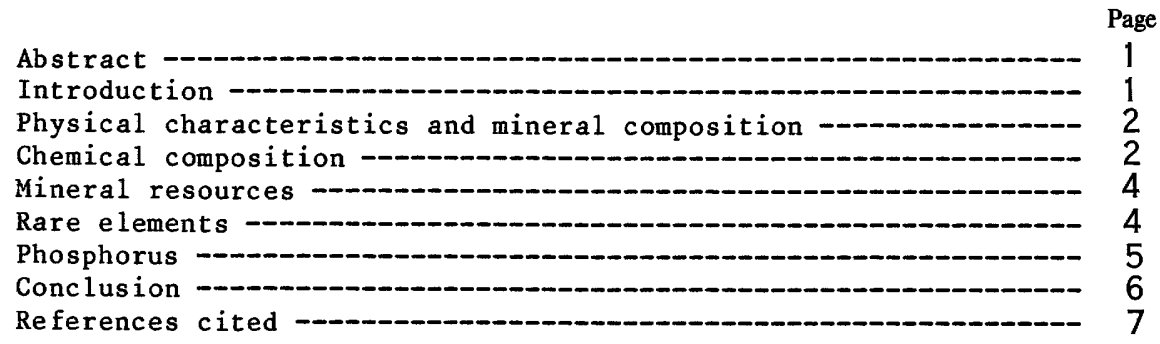

TABLES

1. Identified minerals, compounds, and native Page elements in Palo Alto ash- 1

2. Chemical composition of $\mathrm{Palo}$ Alto ash

3. Chemical composition of the ash of incinerated sewage from Palo Alto and other U.S. cities--_-_ 4

4. Amounts of elements dissolved in HC1 


\title{
Gold, Silver, and Other Resources in the Ash of Incinerated Sewage Sludge at Palo Alto, California--A Preliminary Report
}

\author{
By R. A. Gulbrandsen, Norma Rait, Donathan J. Krier, \\ Philip A. Baedecker, and Anne Childress
}

\begin{abstract}
The ash of incinerated sewage sludge in Palo Alto, Calif., contains large contents of gold ( 30 parts per million) and silver (660 ppm). As much as 9000 metric tons of ash is piled in the city dump and comprises a gold and silver deposit that has a market value of about $\$ 2.5$ million. Annual production of ash is about 1800 metric tons with a value of nearly $\$ .5$ million. The contents of copper ( $8000 \mathrm{ppm})$ and tin (1000 ppm) increase the value of the ash appreciably. Phosphorus makes up about 6.6 percent of the ash and has a potential value for fertilizer manufacture.

The principal source of the metals appears to be the large electronics industry that is located in the area. Part of the silver likely comes from the photographic industry.

No resources are being recovered presently from the ash of incinerated sewage sludge in the United States. The ash from the Palo Alto sewage sludge appears to offer an attractive opportunity for the profitable recovery of a number of mineral resources.
\end{abstract}

\section{INTRODUCTION}

Bizarre as it may seem, a gold and silver deposit is located in the city dump of Palo Alto, Calif. The deposit is composed of incinerated sewage sludge. The multiple hearth incinerator handles about 6500 metric tons (dry basis) of sludge annually and yields about 1800 metric tons of ash. As much as 9000 metric tons has been piled in the city dump. The temperature of incineration is about $760^{\circ} \mathrm{C}$, and very little unburned material remains in the ash.

The apparent value of the deposit, based on a gold price of $\$ 175$ per troy ounce and a silver price of $\$ 5.00$ per troy ounce, is nearly $\$ 2.5 \mathrm{million}$, and the apparent value of the ash produced annually is almost $\$ .5$ million. Significant amounts of phosphate, copper, and tin increase the value of the ash appreciably.

The sewage system serves the cities of Mountain View, Los Altos, Los Altos Hills, Stanford, and East Palo Alto, in addition to Palo Alto itself. The principal source of the metals appears to be the large electronics industry that is located in the area served by the sewage system, although the photographic industry may contribute a significant part of the silver.

The remarkably large gold and silver contents of the ash were indicated first by semiquantitative spectrographic analyses made as part of a study of the ash as a potential source of phosphate for fertilizer. The spectrographic analyses were subsequently confirmed by neutron activation analysis for gold and atomic absorption analysis for silver.

Analytical data of two samples that were collected 5 months apart at the incinerator are presented here. The close similarity in composition of the samples with one another as well as with another sample that is reported by Gabler and Neylan (1977) indicates that the ash is remarkably homogeneous. Since the press release by the U.S. Geological Survey, in March, 1977, of the gold and silver contents of the ash, the Palo Alto City staff reports (oral commun., May 23, 1978) that subsequent determinations of the amounts of gold and silver in ash from the incinerator have not changed significantly. 
In addition to the analytical data, this report treats some features of the ash that bear on recovery methods for some of the elements, particularly phosphorus. This study is not intended to be thorough or comprehensive in scope.

Acknowledgments.--We are grateful to the city of Palo Alto for allowing us to make this study. We especially thank Raymond $\mathrm{H}$. Remmel, Chief Engineer, Water Quality Control, for providing the ash samples and describing the incineration process. We also thank Mark Harris, Acting Chief Engineer of the Water, Gas, and Sewer Division for information about the city's plans for sale of the ash.

\section{PHYSICAL CHARACTERISTICS AND MINERAL COMPOSITION}

The reddish-brown fine-grained ash. is similar in general appearance to natural material. More than 80 percent of the ash is smaller than $.061 \mathrm{~mm}$ in grain size ( $\mathrm{silt}$ and clay). Size fractions are presented in the following table (sample taken in October 1975).

\begin{tabular}{|c|c|}
\hline $\begin{array}{c}\text { Grain size } \\
(\mathrm{mm}) \\
>0.833 \\
.495-.833 \\
.149-.495 \\
.061-.149 \\
<.061\end{array}$ & 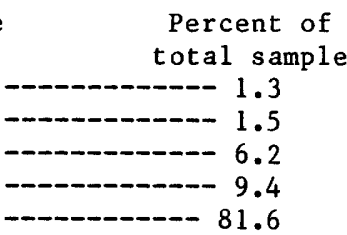 \\
\hline
\end{tabular}

Microscopic examination shows that the ash differs markedly from natural materials in containing bits of aluminum foil, wire, common glass, and animal bone. X-ray diffraction reveals the presence of another anomalous component, silicon, which is an important semiconductor used by the electronics industry.

The minerals, compounds, and native elements in the ash that have been identified are listed in table 1 . Most are minerals, that is, naturally occurring chemical compounds and native elements, and many of them, particularly quartz, plagioclase, potassium feldspar, amphibole, and pyroxene, are likely derived from the sand, soil, and dust of the area. Other minerals, such as corundum and garnet, have been used by man as abrasives and then discarded. Possibly some part of all of the minerals have been used in some way. The only identified minerals in the ash that do not occur naturally are aluminum, silicon, and silicon carbide. Some of the minerals are synthetic, at least in part; cristobalite, for example, is commonly formed in ceramics. Much of the hematite and probably all of the whitlockite are developed during the incineration of the sludge.

The number of identified constituents in the ash is unusually large in comparison with natural sediment, and, because of the heterogeneous origin of sewage, many more are undoubtedly present. Quartz, cristobalite, whitlockite, and apatite are the major components, and many others occur in significant amounts.

Table 1.--Identified minerals, compounds, and native elements in Palo Alto ash

\begin{tabular}{|c|c|}
\hline $\begin{array}{l}\text { Elements: } \\
\text { Iron } \\
\text { Aluminum } \\
\text { Gold } \\
\text { Silicon }\end{array}$ & $\begin{array}{l}\text { Oxides: } \\
\text { Hematite (ferric oxide) } \\
\text { Corundum (aluminum oxide) } \\
\text { Rutile (titanium oxide) } \\
\text { Quartz (silicon oxide) } \\
\text { Cristobalite (silicon oxide) }\end{array}$ \\
\hline $\begin{array}{l}\text { Silicates: } \\
\text { Plagioclase } \\
\text { Potassium feldspar } \\
\text { Amphibole } \\
\text { Pyroxene } \\
\text { Muscovite } \\
\text { Talc } \\
\text { Garnet } \\
\text { Zircon }\end{array}$ & $\begin{array}{l}\text { (sodium calcium aluminum silicate) } \\
\text { (potassium aluminum silicate) } \\
\text { (many compositional variables) } \\
\text { (many compositional variables } \\
\text { (potassium aluminum hydroxyl silicate) } \\
\text { (magnesium hydroxyl silicate) } \\
\text { (many compositional variables) } \\
\text { (zirconium silicate) }\end{array}$ \\
\hline $\begin{array}{l}\text { Phosphates: } \\
\text { Whit lockite } \\
\text { Carbonate hydroxyl }\end{array}$ & $\begin{array}{l}\text { (calcium magnesium carbonate(?) phosphate) } \\
\text { apatite (calcium hydroxyl carbonate phosphate) }\end{array}$ \\
\hline $\begin{array}{l}\text { Carbonate: } \\
\text { Calcite } \\
\text { Carbide: } \\
\text { silicon carbide }\end{array}$ & (calcium carbonate) \\
\hline
\end{tabular}

\section{CHEMICAL COMPOSITION}

Data that we have obtained on the chemical composition of ash from Palo Alto are presented in table 2. Other constituents that have not been determined but that are known qualitatively to be present are carbon as inorganic carbonate, carbon of unburned organic material, and sulfur as sulfate. Also included in the table is a measure of concentration of the elements relative to their respective abundances in the continental crust of the earth, called the concentration factor (C.F.). Table 3 , compares the average composition of the ash that we determined with an analysis of the ash made by Gabler and Neylan (1977) of the U.S. Bureau of Mines as well as with a summary of their analyses of incinerated sludge ashes of other United States cities. The analyses of the Palo Alto ash compare well for most constituents. The large difference between the $t$ in determinations deserves attention, however, because of the appreciable apparent value of the $t$ in in the ash. Since our determination of tin was only semiquantitative, we accept the quantitative determination, $1000 \mathrm{ppm}$, of Gabler and Neylan as the better one. Comparison of the 14 rare elements common to both the average composition of Palo Alto ash and the average composition of ash from 13 plants in other U.S. cities shows that the concentrations of 10 of the elements are greater in the Palo Alto ash and that 8 of these 10 occur in amounts more than twice as large as those in the ash of other cities. Gold was not detected in the ash of other cities, and compared to the Palo Alto ash, silver is present in much smaller 
Table 2.--Chemical composition of Palo Alto ash

[Sample 1 is bulk sample of October, 1975; sample 1A is the grain-size fraction of sample 1 that is less than $.053 \mathrm{~mm}$; sample 1B is the acid-insoluble (HCl:H20-1:3) of sample lA; sample 2 is bulk sample of March 1976. Footnotes: 1, semiquantitative spectrographic analysis by N. Rait; 2, instrumental neutron-activation analysis (INAA) by P. A. Baedecker; 3, atomic absorption spectrophotometric (AAS) analysis by Anne Childress; 4, average of INAA and AAS; 5, X-ray spectrographic analysis by R. A. Gulbrandsen; 6, spectrophotometric analysis by R. A. Gulbrandsen; 7, continental crust (Taylor, 1964); 8, Concentration factor (C.F.) = average ash/continental crust].

\begin{tabular}{|c|c|c|c|c|c|c|c|}
\hline \multirow[b]{2}{*}{ Element } & \multicolumn{4}{|c|}{ Sample No. } & \multirow{2}{*}{$\begin{array}{c}\text { Average of } \\
1 \text { and } 2\end{array}$} & \multirow{2}{*}{$\begin{array}{c}\text { Crustal } \\
\text { abundance }\end{array}$} & \multirow[b]{2}{*}{ C.F. ${ }^{8}$} \\
\hline & 1 & $1 \mathrm{~A}$ & $1 \mathrm{~B}$ & 2 & & & \\
\hline \multicolumn{8}{|c|}{ Percent by weight } \\
\hline $\mathrm{Si}^{1}-\infty-\infty-\infty-\infty$ & 21.0 & 17.0 & - & 23.0 & 22.0 & 28.15 & 0.8 \\
\hline $\mathrm{Al}^{1}-\cdots-\infty-$ & 5.4 & 4.4 & 6.4 & 4.8 & 5.1 & 8.23 & .6 \\
\hline $\mathrm{Fe}^{2}--------$ & 4.8 & 5.4 & 3.2 & 4.1 & 4.4 & 5.63 & .8 \\
\hline 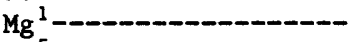 & 1.9 & 1.7 & .9 & 1.8 & 1.8 & 2.33 & .8 \\
\hline 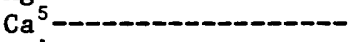 & 8.6 & 8.7 & .4 & 7.0 & 7.8 & 4.15 & 1.9 \\
\hline 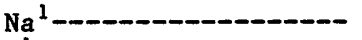 & 1.1 & 1.3 & .9 & 1.1 & 1.1 & 2.36 & .5 \\
\hline 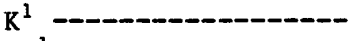 & .5 & .5 & .6 & .4 & .4 & 2.09 & .2 \\
\hline 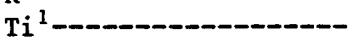 & .3 & .3 & .6 & .3 & .3 & .57 & .5 \\
\hline 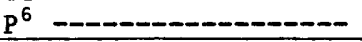 & 6.2 & 7.4 & .3 & 7.1 & 6.6 & .105 & 63 \\
\hline \multicolumn{8}{|c|}{ Parts per million } \\
\hline $\mathrm{Ag}^{4}-\infty-\infty-\infty$ & 680 & 760 & 710 & 635 & 660 & 0.07 & 9400 \\
\hline $\mathrm{Au}^{2}-1-$ & 28 & 34 & 64 & 32 & 30 & .004 & 7500 \\
\hline $\mathrm{B}^{1}-\cdots$ & 89 & 59 & 51 & 74 & 82 & 10 & 8.2 \\
\hline $\mathrm{Ba}^{2}-\cdots$ & 2600 & 2750 & 1850 & 2500 & 2550 & 425 & 6 \\
\hline 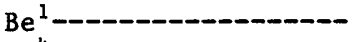 & 5 & 5 & 8 & 13 & 9 & 2.8 & 3.2 \\
\hline $\mathrm{Cd}^{4}-\cdots$ & 68 & 80 & - & 99 & 84 & .2 & 420 \\
\hline $\mathrm{Ce}^{2}-\cdots---\cdots$ & 170 & 200 & 62 & 180 & 175 & 60 & 2.9 \\
\hline $\mathrm{Co}^{2}--$ & 360 & 425 & 170 & 230 & 295 & 25 & 12 \\
\hline 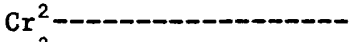 & 1450 & 1700 & 2150 & 1200 & 1300 & 100 & 13 \\
\hline 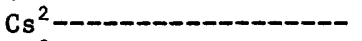 & 18 & 22 & 22 & 12 & 15 & 3 & 5 \\
\hline $\mathrm{Cu}^{3}-\ldots$ & 7400 & 8200 & 6400 & 8600 & 8000 & 55 & 145 \\
\hline 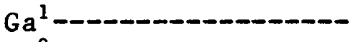 & 98 & 100 & 84 & 290 & 190 & 15 & 13 \\
\hline $\mathrm{Hf}^{2}-\cdots-\infty-\infty-m$ & 5 & 6 & 11 & 7 & 6 & 3 & 2 \\
\hline 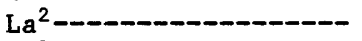 & 67 & 81 & 35 & 65 & 66 & 30 & 2.2 \\
\hline 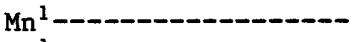 & 680 & 650 & 270 & 580 & 630 & 950 & .7 \\
\hline 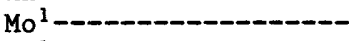 & 23 & 14 & 7 & 27 & 25 & 1.5 & 16 \\
\hline $\mathrm{Nb}^{1}-\infty-m-m-n$ & 17 & 17 & - & 23 & 20 & 20 & 1 \\
\hline $\mathrm{Nd}^{2}--------$ & 50 & 55 & 18 & 44 & 47 & 28 & 1.7 \\
\hline $\mathrm{Ni}^{3}-\mathrm{n}-\mathrm{n}$ & 1700 & 2200 & 1400 & 1100 & 1400 & 75 & 19 \\
\hline 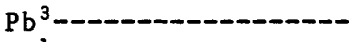 & 1800 & 2300 & 770 & 2000 & 1900 & 12.5 & 150 \\
\hline 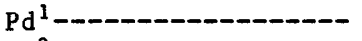 & 5 & 5 & 11 & 4 & 4 & .01 & 400 \\
\hline $\mathrm{Sb}^{2}---1---$ & 14 & 18 & 14 & 24 & 19 & .2 & 95 \\
\hline $\mathrm{Sc}^{2}-----------$ & 4 & 4 & 4 & 3 & 4 & 22 & .2 \\
\hline 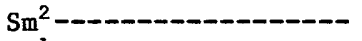 & 4 & 4 & 2 & 3 & 4 & 6 & .7 \\
\hline $\mathrm{Sn}^{1}-\infty-\infty-\infty-\infty-\infty-\infty$ & 3100 & 3600 & 3500 & 3000 & 3050 & 2 & 1500 \\
\hline 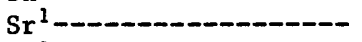 & 430 & 400 & 61 & 480 & 455 & 375 & 1.2 \\
\hline $\mathrm{Ta}^{2}-\cdots--$ & 8 & 9 & 17 & 6 & 7 & 2 & 3.5 \\
\hline $\mathrm{Th}^{2}-\cdots-\cdots$ & 6 & 7 & 7 & 4 & 5 & 9.6 & .5 \\
\hline 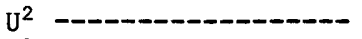 & 11 & 12 & 2 & 14 & 12 & 2.7 & 4.4 \\
\hline $\mathrm{V}^{1}--0-0-0-0-0-1--$ & 41 & 33 & 33 & 43 & 42 & 135 & .3 \\
\hline 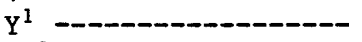 & 8 & 7 & 6 & 8 & 8 & 33 & .2 \\
\hline 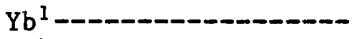 & .8 & .6 & .7 & .7 & .8 & 3 & .3 \\
\hline 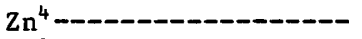 & 3700 & 4500 & 3100 & 4000 & 3850 & 70 & 55 \\
\hline $\mathrm{Zr}^{1}-\cdots-1--\infty-\cdots$ & 270 & 240 & 580 & 340 & 305 & 165 & 1.8 \\
\hline
\end{tabular}

amounts. The only other city that is known to have a significant amount of gold in its sewage is Sunnyvale, which is located a few miles south of $\mathrm{Palo}$ Alto and which has a large electronics industry like that of Palo Alto. An analysis of this sewage by
K. E. McAbee (San Jose Mercury, 1977; oral commun., 1977) shows a gold content of 0.1 0.2 troy ounce per ton of wet sludge. This content of gold in wet sludge would be concentrated a number of times if it were incinerated, and the ash would likely 
contain about the same amount of gold as the ash of Palo Alto's incinerated sludge. Silver in the wet sludge was reported to be about 0.5 troy ounce per ton, an amount that would be much less than that of Palo Alto's ash even after incineration.

Phosphorus is a major constituent of the ash, averaging 6.6 percent by our analysis, and is about double the average amount for other U.S. cities (table 3 ). Analyses of Toronto, Ontario, ash have an average of 5.1 percent phosphorus (Diosady, 1975, p. 11). The reason for the high amount in the Palo Alto ash is not known.

Table 3.--Chemical composition of ash of incinerated sewage sludge from Palo AIto and other U.S. cities

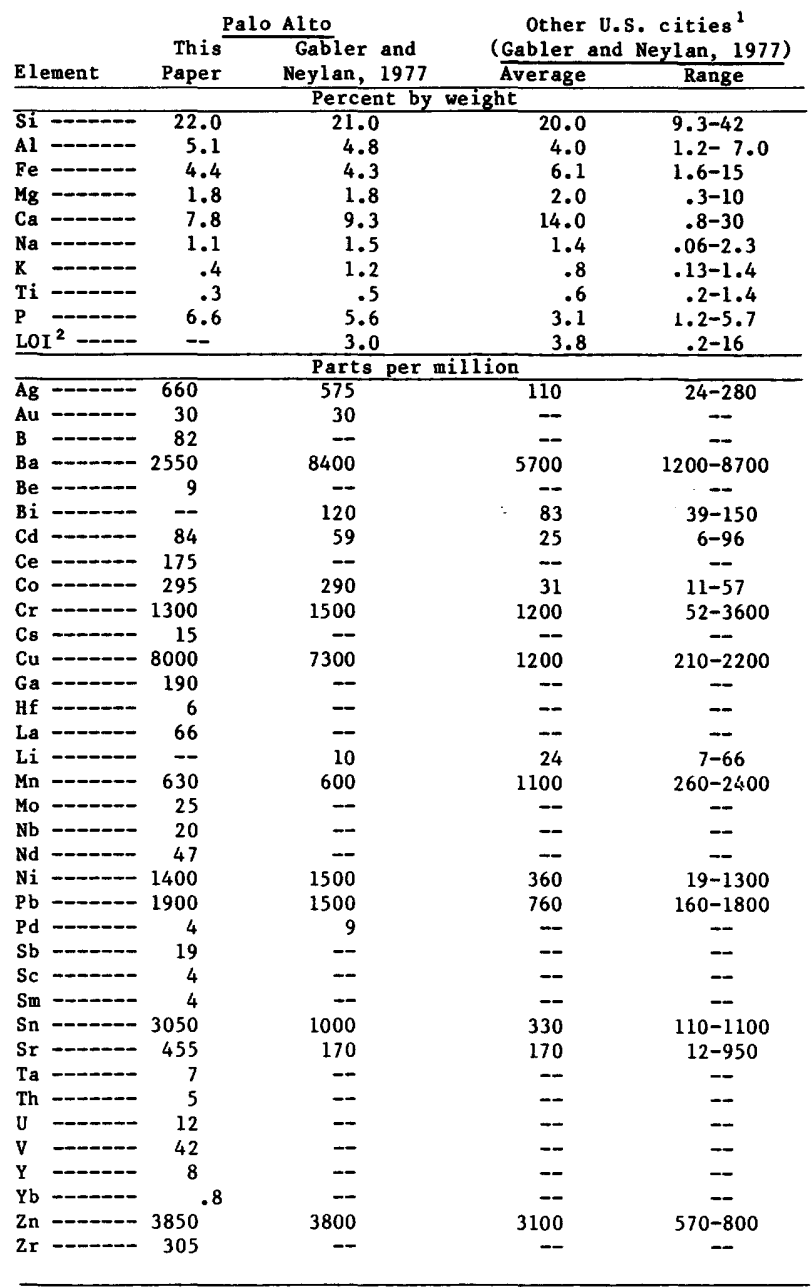

${ }^{1}$ Albany, N.Y, : At lanta, Ga.; Cleveland, Ohio; Detroit, Mich.; Laure 1, Md; Minneapolis - St. Paul, Minn. ( 3 plants); Monterey, Calif; St. Louis, Mo. (2 plants); San Mateo, Calif.; and Savannah, Ga.

${ }^{2}$ LOI is loss on ignition.

\section{MINERAL RESOURCES}

The concentration factors (C.F.) shown in table 2 provide one means of judging the economic potential of the elements in the Palo Alto ash. McKelvey (1960) shows that concentration factors of the elements in ore deposits range from about 3 to 10,000 and are, in general, inversely proportional to the respective abundances of the elements in the Earth's crust. Abundant elements, such as aluminum and iron have C.F.'s less than 10. Phosphorus, the eleventh most abundant element, has C.F.'s in commercial deposits from about 20 to 150 ; the C.F. in the Palo Alto ash is 63. Silver is the most highly concentrated element in the ash, with a C.F. of 9400 , and is present in an amount that is similar in magnitude to the rich deposits of the Coeur D'Alene district in Idaho (Heyl and others, 1973, p. 594). Gold is the next highest, with a C.F. of 7500 , and the amount of gold is about double the average grade that is mined currently in the world (simons and Prinz, 1973, p. 274). Tin is highly concentrated with a C.F. of 500 (using the value of Gabler and Neylan, 1977), but not especially high in actual grade. Palladium has a C.F. of 400 and would likely be recovered with gold. The C.F. of copper is only 145, but the amount present is of common ore grade. Cadmium is highly concentrated, with a C.F. of 420 , but the amount present in the ash is not of significant value. Lead, with a C.F. of 150 , is also of only small value. Seven more elements-cobalt, chromium, gallium, molybdenum, nickel, antimony, and zinc-have factors greater than 10 but are present in amounts that are of low value. All of the elements that have concentration factors greater than 10 make the Palo Alto ash an unusual material in comparison with the natural materials of the Earth's crust. Average shale (Turekian and Wedepoh1, 1961), for example, has only one rare element with a C.F. as high as $10 \mathrm{from}$ the group of those reported in the ash. Compared to natural materials, the ash may even be unique in containing a suite of elements that are significantly concentrated but that are of diverse geochemical affinities.

\section{RARE ELEMENTS}

Methods of recovery of some of the rare elements from the ashes of incinerated sewage sludges have been studied by Diosady (1975), Oliver and Carey (1976), and Gabler and Neylan (1977). All of the studies contain many data on the solubility of the elements in various kinds of solvents. Gabler and Neylan are the only ones to work on the Palo Alto ash and on the extraction of gold and silver in particular. They 
found in preliminary studies that a two-stage leach of the ash with boiling concentrated hydrochloric acid and a strong alkaline sodium cyanide solution was required to extract 77 percent of the gold and 40 percent of the silver. The only other extractive data on gold and silver in the Palo Alto ash are those that we obtained (sample 1B, table 2). They comprise the determinations made on the acid-insoluble part of sample 1A. Hydrochloric acid was used in a $1: 3$ ratio of concentrated $\mathrm{HCl}$ to $\mathrm{H}_{2} \mathrm{O}$ at ambient temperature. The amount of gold, $64 \mathrm{ppm}$, indicates that essentially all of the gold is insoluble in the hydrochloric acid solution, and about half of the silver is not dissolved. We have observed gold in the metallic state as individual plates and variously shaped chunks and also incorporated in particles of fused or aggregated material. No other mode of occurrence has been recognized although Gabler and Neylan's data indicate that more than one exists. At least two modes of occurrence of silver are present, as our solubility data indicate as well as those of Gabler and Neylan's, but none has been identified. We found that the silver dissolved in the hydrochloric acid solution could be separated effectively by a small increase in the solution's pH. The addition of sodium hydroxide solution precipitated silver chloride, the mineral ceragyrite.

The recovery of rare elements in the Palo Alto ash is complicated by the number of elements that are present in significant amounts, as well as by the lack of knowledge about the elements' modes of occurrence. The ash is a new kind of ore for which efficient extractive methods for the greatest number of elements possible have yet to be developed.

\section{PHOSPHORUS}

The phosphorus content of worldwide commercial phosphate deposits ranges from about 2.2 to 16 percent. A proposed mine by U.S. Gypsum at Pine Mountain, Ventura Co., California, would have ore with an average grade of 3.7 percent phosphorus (Evans, 1976 , p. 275) and would be the only phosphate mine in California that is mined for phosphate products (some phosphatic rock is mined for use as a soil conditioner). Nearly all of the phosphorus mined in the United States occurs as carbonate fluorapatite, a phosphate mineral that is formed in the marine environment. About 83 percent of U.S. consumption is for fertilizer and animal feed supplement, about 9 percent for detergents, and the remainder is used in a large number of other products (Stowasser, 1977, p. 6).

Fertilizer manufacture employs two basic processes. In the first, the water- insoluble apatite that is mined is converted into soluble monocalcium phosphate by sulfuric acid. Gypsum is also formed in the reaction. The product is ordinary superphosphate, a fertilizer that is declining in popularity.

In the second process, sufficiently more sulfuric acid than that required in the superphosphate process is added in order to dissolve all of the phosphate compounds and yield phosphoric acid and gypsum. The gypsum and other insoluble residues are removed by filtration, leaving a phosphoric acid product. This method of processing is popular because many kinds of fertilizers $c$ an be made from phosphoric acid. There are three general types:

1. Triple superphosphate. A solid fertilizer made by the reaction of phosphoric acid with apatite ore. It contains up to three times as much available $\mathrm{P}_{2} \mathrm{O}_{5}$ as ordinary superphosphate.

2. Mono- and diammonium phosphates. Solid fertilizers that can be mixed with potassium salts to make all grades of three-component (nitrogen-phosphorus-potassium) fertilizers.

3. Liquid fertilizers that contain phosphate and other element nutrients.

Phosphorus compounds that have been identified in the $\mathrm{Palo}$ Alto ash are the minerals carbonate hydroxyl apatite and whitlockite. Both are principally calcium phosphates like the apatite of most commercial ore deposits and are similarly soluble in acid solutions. The amount of calcium in the ash, however, is insufficient to account for all of the phosphorus in these compounds. The presence of a small amount of calcium carbonate (calcite) further accentuates the calcium deficiency. It seems most likely that iron, and possibly aluminum, are combined with the excess phosphate. A rough calculation indicates that about $35-40$ percent of the ash is composed of phosphate compounds.

The amounts of constituents of the ash that are dissolved in the hydrochloric acid solution along with those of phosphate compounds are shown in table 4. Sample 1B is the acid-insoluble part, 53 percent, of 1A. The amount of an element that is dissolved, therefore, equals the total (in 1A) minus the amount that remains in the acid-insoluble part (percent in 1B multiplied by .53 , the proportion of the total $1 \mathrm{~A}$ that is acid insoluble). The amount of phosphorus dissolved, for example, is: $\mathrm{P}$ (dissolved) $=\mathrm{P}$ (total) $\mathrm{P}$ (acid insoluble), 7.2 percent=7.4 percent-. 2 percent (. $3 x .53)$. Nearly all the phosphorus, calcium, strontium, and uranium are dissolved (table 4) :- 
Table 4.--Amounts of elements dissolved in HCL

ISamples IA and 1B from table 2. Part in A.I. is amount that remains in acid-insoluble part of $1 \mathrm{~A}$ (percent in 1B multiplied by .53 , the proportion of total in $1 \mathrm{~A}$ that is acid insoluble). Part dissolved is total in $1 \mathrm{~A}$ minus part of $1 \mathrm{~A}$ that is acid insoluble. Percent dissolved is part of $1 \mathrm{~A}$ dissolved relative to total in $1 \mathrm{~A}$.

\begin{tabular}{|c|c|c|c|c|c|c|}
\hline \multicolumn{2}{|c|}{ Element } & $\begin{array}{c}\text { Sample } \\
\text { IA }\end{array}$ & $\begin{array}{c}\text { Sample } \\
\text { 1B }\end{array}$ & $\begin{array}{c}\text { Part } \\
\text { in A.I. }\end{array}$ & $\begin{array}{c}\text { Part } \\
\text { dissolved }\end{array}$ & $\begin{array}{c}\text { Percent } \\
\text { dissolved }\end{array}$ \\
\hline & & & & \multicolumn{3}{|c|}{ Percent by weight } \\
\hline$\overline{\mathrm{Si}}$ & & 17 & -- & -- & -- & -- \\
\hline Al & --- & 4.4 & 6.4 & 3.4 & 1.0 & 23 \\
\hline $\mathbf{F e}$ & --- & 5.4 & 3.2 & 1.7 & 3.7 & 68.5 \\
\hline Mg & --- & 1.7 & 0.9 & .5 & 1.2 & 71 \\
\hline $\mathrm{Ca}$ & --- & 8.7 & 0.4 & .2 & 8.5 & 98 \\
\hline $\mathrm{Na}$ & ---- & 1.3 & 0.9 & .5 & .8 & 62 \\
\hline $\mathrm{K}$ & --- & .5 & 0.6 & .3 & .2 & 40 \\
\hline $\mathrm{Ti}$ & --- & .3 & 0.6 & .3 & 0 & 0 \\
\hline \multirow[t]{3}{*}{$\underline{\mathbf{P}}$} & ---- & 7.4 & 0.3 & .2 & 7.2 & 97 \\
\hline & & & & \multicolumn{3}{|c|}{ Parts per million } \\
\hline & --- & 760 & 710 & 380 & 380 & 50 \\
\hline $\mathrm{Au}$ & --- & 34 & 64 & 34 & 0 & 0 \\
\hline B & --- & 59 & 51 & 27 & 32 & 54 \\
\hline $\mathrm{Ba}$ & --- & 2750 & 1850 & 980 & 1770 & $64^{-}$ \\
\hline $\mathrm{Be}$ & --- & 5 & 8 & 4 & 1 & 20 \\
\hline $\mathrm{Cd}$ & --- & 80 & - & -- & -- & - \\
\hline $\mathrm{Ce}$ & --- & 200 & 62 & 33 & 167 & 93.5 \\
\hline Co & -- & 435 & 170 & 90 & 345 & 79 \\
\hline $\mathrm{Cr}$ & -- & 1700 & 2150 & 1100 & 600 & 35 \\
\hline Cs & --- & 22 & 22 & 12 & 10 & 45 \\
\hline $\mathrm{Cu}$ & --- & 8200 & 6400 & 3400 & 4800 & 59 \\
\hline $\mathrm{Ga}$ & --- & 100 & 84 & 44.5 & 55.5 & 55.5 \\
\hline Hf & --- & 6 & 11 & 6 & 0 & 0 \\
\hline La & --- & 81 & 35 & 19 & 62 & 77 \\
\hline Mn & $-\infty$ & 650 & 270 & 140 & 510 & 78 \\
\hline Mo & --- & 14 & 7 & 4 & 10 & 71 \\
\hline $\mathrm{Nb}$ & --- & 17 & -- & -- & -- & -- \\
\hline $\mathrm{Nd}$ & $-\infty$ & 55 & 18 & 9.5 & 45.5 & 83 \\
\hline $\mathrm{Ni}$ & $\cdots$ & 2200 & 1500 & 795 & 1405 & 64 \\
\hline $\mathbf{P b}$ & --- & 2300 & 770 & 410 & 1890 & 82 \\
\hline Pd & --- & 5 & 11 & 6 & 0 & 0 \\
\hline $\mathbf{S b}$ & --- & 18 & 14 & 7 & 11 & 61 \\
\hline $\mathrm{Sc}$ & --- & 4 & 4 & 2 & 2 & 50 \\
\hline Sm & $-\cdots$ & 4 & 2 & 1 & 3 & 75 \\
\hline Sn & --- & 3600 & 3500 & 1900 & 1700 & 47 \\
\hline $\mathrm{Sr}$ & --- & 400 & 61 & 32 & 368 & 92 \\
\hline $\mathrm{Ta}$ & --- & 9 & 17 & 9 & 0 & 0 \\
\hline Th & --- & 7 & 7 & 4 & 3 & 43 \\
\hline $\mathbf{U}$ & --- & 12 & 2 & 1 & 11 & 92 \\
\hline v & --- & 33 & 33 & 17.5 & 15.5 & 47 \\
\hline $\mathrm{Y}$ & --- & 7 & 6 & 3 & 4 & 57 \\
\hline $\mathrm{Yb}$ & --- & .6 & .7 & .4 & .2 & 33 \\
\hline $\mathrm{Zn}$ & --- & 4500 & 3100 & 1600 & 2900 & 64 \\
\hline $\mathrm{Zr}$ & -- & 240 & 580 & 310 & 0 & 0 \\
\hline
\end{tabular}

Strontium and uranium probably occur in the calcium phosphate compounds as they do in natural phosphate deposits. Nearly insoluble elements are gold, titanium, hafnium, palladium, and zirconium. The more abundant rare elements in the ash are dissolved in significant amounts: silver, 50 percent; barium, 64 percent; chromium, 35 percent; copper, 59 percent; nickel, 64 percent; lead, 82 percent; tin, 47 percent; and zinc, 64 percent.

It seems likely from these data that any process for making fertilizer from the ash will have to include a means of separating undesirable elements from the fertilizer product. The amount of dissolved lead, for example, is especially large and potentially hazardous to health if it enters the food chain in fertilizer.

Treatment of the ashes that were studied by Diosady (1975) and 01 iver and Carey (1976) includes the recovery of a number of rare elements as well a high-quality phosphate fertilizer product. In general, the principal procedures include the solution of rare elements and phosphate in hot sulfuric acid solutions; separation of the rare elements by ion exchange and sulfide precipitation, or electrolysis; and the recovery of the phosphorus as phosphoric acid or ammonium phosphate.

Phosphorus was found to be the resource of greatest value in the ashes investigated by Diosady (1975) and Oliver and Carey (1976), and Diosady concluded that only the recovery of phosphorus seemed economically possible. The recovery system for phosphorus and some other elements that was proposed by 01 iver and Carey was considered likely to be economicaliy feasible only for very large sewage plants.

\section{CONCLUSION}

Recycling of mineral resources is of increasing importance as the primary deposits become depleted or more costly to develop, as environmental concerns restrict or prohibit the development of new deposits, and as the nation strives to maintain or gain independence from foreign sources for some resources.

No resources are recovered presently from ash of incinerated sewage sludge in the United States, although a potential is recognized, some research into recovery processes has been done, and additional work is underway. Part of the impetus for the recovery of element resources arises from the need to ensure that the ash is safe for disposal in the environment. It is the large number of potential resources in ash that poses difficult recovery problems as well as offering opportunities for recycling.

The Palo Alto ash is especially rich in resources. The remarkably large amounts of gold, silver, phosphorus, tin, and copper, in particular, present an unusual opportunity for pioneer work in profitable recycling, which could lead also to the development of processes for the recovery of other element and mineral constituents in the ash. 


\section{REFERENCES CITED}

Diosady, L. L., 1975, Recycling of incinerator ash: Ontario Ministry of the Environment, Research Report $19,82 \mathrm{p}$.

Evans, J. R., 1976, Economic evaluation of Pine Mountain phosphate deposit, Ventura County, California: California Division of Mines and. Geology, California Geology, Dec. P. 275-279.

Gabler, R. C., and Neylan, D. L., 1977 , Incinerated municipal sewage sludge as a secondary resource for metals and phosphorus, in National Conference on Sludge Management, Disposal and Utilization, 3rd, Miami Beach, 1976, Proceedings: Rockville, Md., Information Transfer, p. 197-200.

Heyl, A. V., Ha11, W. E., Weissenborn, A. E., Stager, H. K., Puffett, W. P., and Reed, B. L., 1973, Silver, in Brobst, D. A., and Pratt, W. P., eds., U.S. mineral resources: U.S. Geological Professional Paper 820, p. 581-604.
McKelvey, V. E., 1960, Relation of reserves of the elements to their crustal abundance: American Journal of Science, v. 258-A, p. 234-241.

01 iver, B. G., and Carey, J. H., 1976, The removal and recovery of metals from sludge and sludge incinerator ash: Ontario Ministry of the Environment, Research Report 33, $58 \mathrm{p}$.

San Jose Mercury, 1977, Gold found in sewage not worth recovery cost: San Jose Mercury, three star ed., p. 25.

Simons, F. S., and Prinz, W. C., 1973, Gold, in Brobst, D. A., and Pratt, W. P., eds., U.S. mineral resources: U.S. Geological Survey Professional Paper 820, p. 263-276.

Stowasser, W. F., 1977, Phosphate: U.S. Bureau of Mines Mineral Commodity Profiles MCP-2, $18 \mathrm{p}$.

Taylor, S. R., 1964, The abundance of chemical elements in the continental crust--a new table: Geochimica et Cosmochimica Acta, v. 28, p. 1273-1285.

Turekian, K. K., and Wedepoh1, K. H., 1961 , Distribution of the elements in some major units of the earth's crust: Geological Society of America Bulletin, v. 72, p. 175-192. 
- 